\title{
Injury frequency and body composition of elite Romanian rugby players
}

\author{
Bogdan ALMĂJAN-GUȚ ${ }^{1}{ }^{1}$, Alexandra-Mihaela RUSU² ${ }^{\text {, Adrian NAGEL }}{ }^{3}$, Claudiu AVRAM ${ }^{4}$
}

\begin{abstract}
Background: The physical exertion in the game of rugby is intense and depends on the playing position. This study hypothesized that peculiarities of body composition are important and should be properly interpreted in order to improve fitness and particularly in order to reduce the risk of injuries. Purpose: The aim of the present paper is to highlight the importance of body composition evaluation and to underline the usefulness of the data thus obtained for both training individualization and sports injuries risk reduction. Material and Methods: Thirty seven senior male rugby players from the former Romanian national team were assessed on body composition using a segmental multi-frequency bio-impedance analyzer InBody 720 (The Body Composition Analyzer - South Korea). We compared the results from both the preseason and the regular season 2012 with the international norms for elite players and we categorized the data by playing positions. Results: We have analyzed the amount of lean mass on each limb (kg), body water content (l), percentage of body fat, bone mineral and protein content $(\mathrm{kg})$. We observed that the number of injuries is directly correlated to high levels of body fat percentage, low lean mass, and edema scores. Conclusions: The risk of injury can be identified among elite rugby players not only by using fitness tests, but also by using a simple and objective test of body composition. These results show how important it is to monitor the level of body fat, lean muscle mass and muscular development in order to modify nutrition and food habits, individualize trainings and thus reduce the number of injuries.
\end{abstract}

Key words: rugby players, exercise training, body composition, injury risk.

\section{Rezumat}

Introducere: În jocul de rugby, efortul este intens și depinde de poziția de joc. Acest studiu a pornit de la ipoteza că particularitățile compoziției corporale sunt importante și ar trebui să fie corect interpretate și utilizate, în vederea optimizării fitnessului, dar mai ales în scopul reducerii riscului de accidentare. Scopul acestei lucrări este de a sublinia importanța evaluărilor obiective referitoare la compoziția corporală și utilitatea datelor astfel obținute, în procesul de individualizare a antrenamentului sportiv și implicit în reducerea riscului de accidentare. Material și metodă: A fost evalută compoziția corporală a 37 de jucători de rugby, membri ai echipei de seniori a Timișoarei, echipă deținătoare a titlului de campioană națională. Această evaluare a fost realizată prin impedanță bioelectrică utilizând InBody 720 (The Body Composition Analyzer - Coreea de Sud). Au fost comparate măsurătorile efectuate în presezon competițional și cele realizate în sezonul competițional 2012, cu normele internaționale stabilite pentru jucătorii profesioniști de rugby, în funcție de postul ocupat în echipă. Rezultate: Au fost analizate: masa slabă la nivelul fiecărui membru (în kg), cantitatea de apă intra și extra-celulară (litri), procentul de grăsime corporală, proteinele (kg) și conținutul de minerale osoase (kg). S-a identificat o corelație directă între numărul de accidentări și nivelurile crescute de grăsime corporală, cantități reduse de masă musculară scheletală, și scorurile de edem. Concluzii: Riscul de accidentare în rândul jucătorilor profesioniști de rugby poate fi identificat nu doar prin utilizarea unor teste de fitness, ci și prin realizarea unei măsurători simple și obiective precum compoziția corporală. Rezultatele acestui studiu atrag atenția asupra importanței pe care o are monitorizarea procentului de țesut adipos, a masei slabe și a dezvoltării musculare, acești parametri având capacitatea de a ghida antrenorii în ajustarea/optimizarea alimentației sportivilor, realizarea de programe de antrenament individualizate, și reducerea numărului de accidentări.

Cuvinte cheie: jucători de rugby, antrenament fizic, compoziție corporală, risc de accidentare.

\footnotetext{
${ }^{1}$ Lecturer, Physical Education and Sports Faculty, West University of Timisoara, e-mail: bogdisport@yahoo.com

${ }^{2}$ Assistant professor, Physical Education and Sports Faculty, West University of Timisoara

${ }^{3}$ Associate professor, Physical Education and Sports Faculty, West University of Timisoara

${ }^{4}$ Associate professor, Physical Education and Sports Faculty, West University of Timisoara
} 


\section{Introduction}

Lately, the rugby game is enjoying a growing worldwide surge of popularity.

Rugby is one of the toughest and most physically demanding team sports and is characterized by aggressive physical contact and high impact activities. The physical exertion in the game of rugby is very intense and depends on the playing position. Rugby has an aggressive reputation. The game is rough and the players do not wear any protection equipment, fact that makes them very vulnerable to injury. Thereby, injury prevention must become a main objective in the training process. A large number of studies sustain the fact that lower limbs are the most frequent sites of injury in rugby, in both match and training conditions [1-9]. In terms of severity of accidents, shoulder injuries are the most severe and need the second most recovery time, after the knee injuries $[2,5,6,10,11]$.

Our study hypothesized that peculiarities of body composition are important and should be properly interpreted in order to improve fitness and particularly in order to reduce the risk of injuries. The main purpose of the present paper is to highlight the importance of body composition evaluation and to underline the usefulness of the data thus obtained for the sports training individualization. In order to optimize the players' fitness and especially in order to reduce the risk of injuries, one must properly understand body composition particularities.

Why we consider that conditioning and proper body composition are important for rugby injury prevention?

- A highly fatigue player is more prone to injuries;

- Overweight players with a high percentage of body fat have diminished body control, inability to coordinate body's actions;

- Lean and body mass can affect technical and tactical proficiency;

- Abnormal percentage of body fat (compared with international norms for each position), or abnormal body fat distribution on the 5 regions of the body, could affect the ability to play effectively and can raise the risk of injury.
In our documentation process on this matter (injury of rugby players), we noticed a lack of research on the peculiarities of anthropometric and physiological characteristics of players according to the demands of this game [12]. We think that anthropometric and body composition observations, together with the metabolic responses during effort, and skills testing, give some important information for the training programs prescription and individualization based on playing position [12].

\section{Materials and methods}

Thirty seven senior male rugby players from the former Romanian national team were assessed on body composition using a segmental multifrequency bio-impedance analyzer (InBody 720, South Korea). Athletes were evaluated in the preseason and in the regular season. Body composition characteristics of the studied rugby team is presented in Table I. The evaluation was conducted in the morning after a fasting period of at least 8 hours.

Table I. Body composition characteristics of the studied rugby team

\begin{tabular}{lrr}
\hline Parameters & Mean & $\begin{array}{r}\text { Standard } \\
\text { deviation }\end{array}$ \\
\hline Height $(\mathrm{cm})$ & 184.6 & 8.2 \\
\hline Weight $(\mathrm{kg})$ & 105.7 & 15.7 \\
\hline Body Fat Mass (kg) & 20.6 & 9.2 \\
\hline Body Fat Percent(\%) & 18.9 & 6.7 \\
\hline Intracellular Water(l) & 39.4 & 4.7 \\
\hline Extracellular Water(l) & 22.9 & 3.0 \\
\hline Soft Lean Mass(kg) & 80.1 & 9.6 \\
\hline Skeletal Muscle Mass(kg) & 49.2 & 5.9 \\
\hline Waist to Hip Ratio & 0.87 & 0.04 \\
\hline Edema Score (ECF/ TBF) & 0.32 & 0.01 \\
\hline Edema Score (ECW/ TBW) & 0.37 & 0.01 \\
\hline
\end{tabular}

We compared the results from both the preseason and the regular season 2012 to international norms for elite players and we categorized the data by playing positions. We tried to find out if some parameters obtained from body composition evaluation can possibly be correlated with the risk 
of injury. We have analyzed the weight, waist circumference, waist to hip ratio (WHR), amount of lean mass on each limb, body fat mass and segmental fat percent, the whole body and segmental fluid and water content. The body composition analyzer (InBody 720) also provides some composite parameters such "Edema score" which represents the ratio between extracellular water and total body water (ECW/TBW), or extracellular fluid and total body fluid ratio (ECF/TBF).

The injury type that we analyzed, the average days needed for recovery and the injury degree, are presented in the Table II. The injury degrees were established based on the number of days needed to fully recover. The highest injury degree corresponds to the highest number of days for recovery

Table II. Common injuries in rugby players and the average duration for full recovery.

\begin{tabular}{lll}
\hline Injuries & $\begin{array}{l}\text { Days needed } \\
\text { for recovery }\end{array}$ & $\begin{array}{l}\text { Injury } \\
\text { degree }\end{array}$ \\
\hline $\begin{array}{l}\text { contusion, muscle } \\
\text { hematoma }\end{array}$ & $3-10$ & 1 \\
\hline stretched muscle & $10-20$ & 2 \\
\hline $\begin{array}{l}\text { pulled muscle - first } \\
\text { degree }\end{array}$ & $21-29$ & 3 \\
\hline ankle sprain, shin splints & $30-50$ & 4 \\
\hline $\begin{array}{l}\text { tendinitis, bursitis, } \\
\text { shoulder impingement, } \\
\text { cervical disc protrusion }\end{array}$ & $50-100$ & 5 \\
\hline $\begin{array}{l}\text { contusion, fracture } \\
\text { fracture, pulled muscle, } \\
\text { degenerative injury }\end{array}$ & $100-150$ & 6 \\
\hline ligament or tendon injury & $200-250$ & 7 \\
\hline
\end{tabular}

\section{Results}

As previous studies pointed out, we noticed that the players' body mass can be a risk factor for sport injury [13]. We found a significant correlation between number of sport injuries suffered by rugby players and their weight $\left(R^{2}=0.22, p=0.003\right)$ (Figure 1).

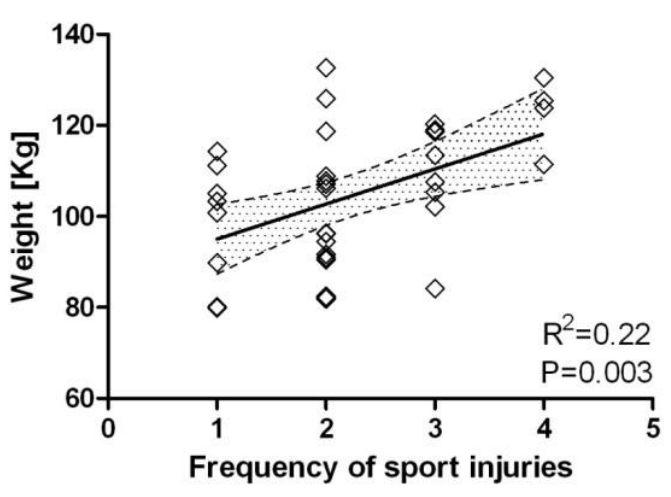

Figure 1. Correlation between frequency of sport injuries and weight

We also found that waist circumference $\left(\mathrm{R}^{2}=0.22\right.$, $\mathrm{p}=0.004)$ and hip circumference $\left(\mathrm{R}^{2}=0.24, \mathrm{p}=0.002\right)$ may be also considered as risk factors for the frequency of sport injuries (Figure 2, 3).

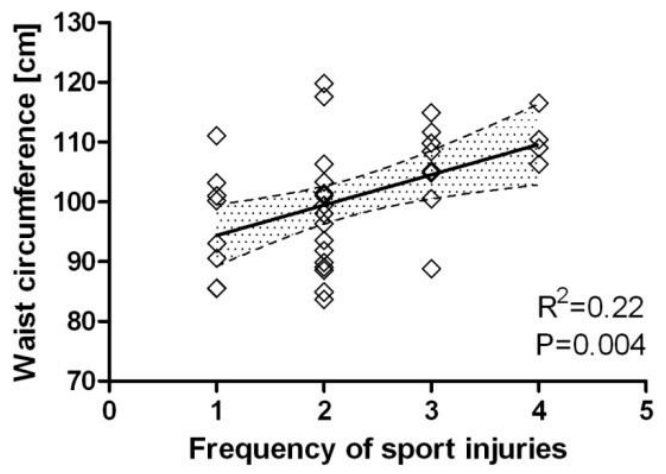

Figure 2. Correlation between frequency of sport injuries and waist circumference

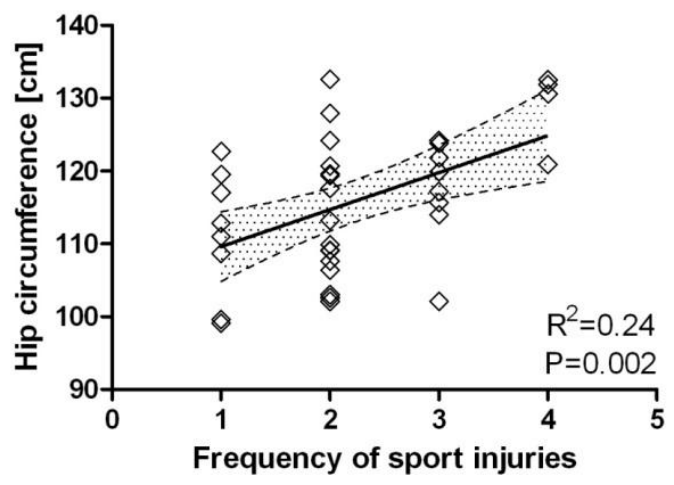

Figure 3. Correlation between frequency of sport injuries and hip circumference 
A highly significant correlation $(\mathrm{P}<0.001)$ was found between injury degree and both Edema Scores (ECF/TBF and ECW/TBW) (Figure 4,5).

Despite the fact that Total Body Water and Intracellular Water alone is not correlated with injury degree; the whole body extracellular water is correlated with the injury degree of rugby players $\left(R^{2}=0.22, p=0.004\right)$.

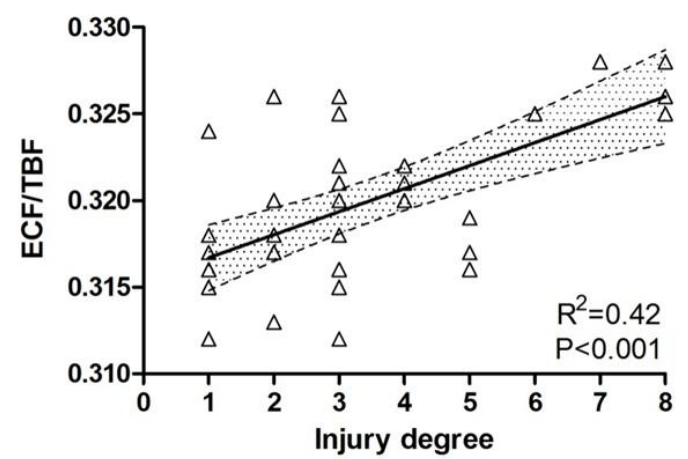

Figure 4. Correlation between Injury degree and Edema Score (ECF/TBF)

ECF: extracellular fluid, TBF: total body fluid, ECF/TBF: edema score

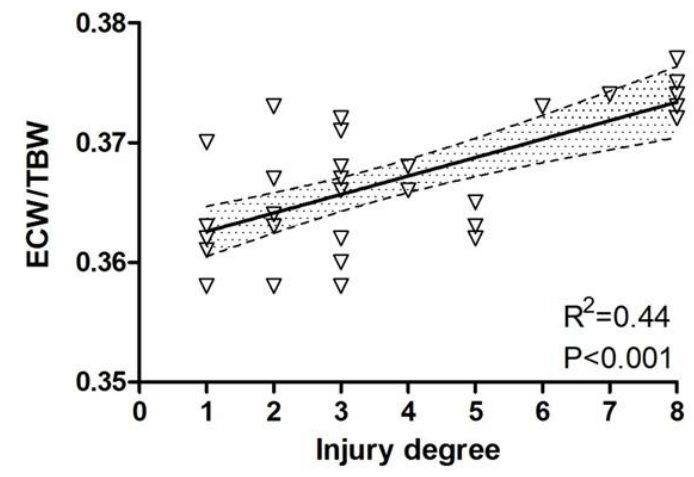

Figure 5. Correlation between Injury degree and Edema Score (ECW/TBW)

ECW: extracellular water, TBW: total body water, ECW/TBW: edema score

The topography of the edema may be also relevant. We noticed that the increased extracellular water on the trunk, but also on the right and left leg correlates with injury degree (Figure 6, 7,8).

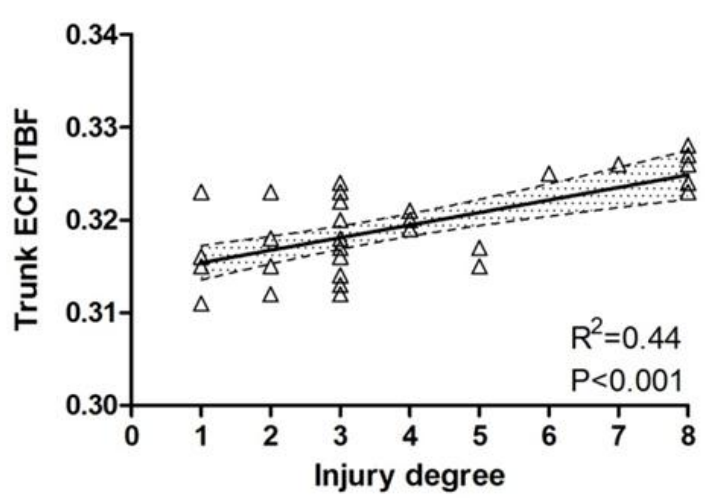

Figure 6. Correlation between Injury degree and Edema Score of the trunk

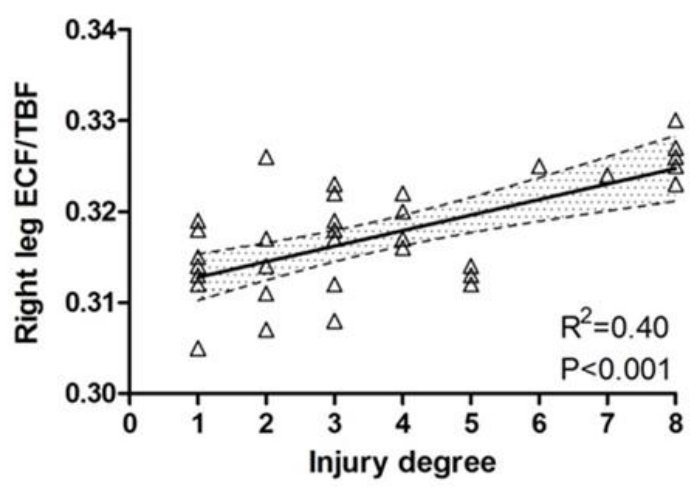

Figure 7. Correlation between Injury degree and Edema Score of the right leg

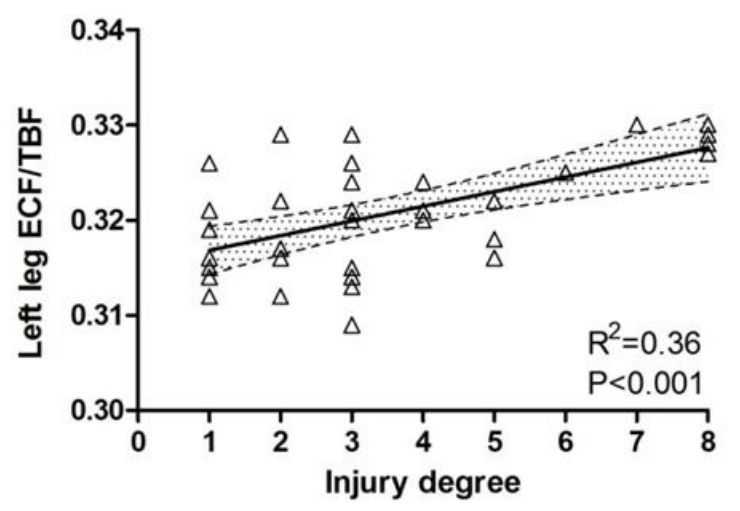

Figure 8. Correlation between Injury Degree and Edema Score of the left leg

\section{Discussion and conclusions}

There are a large number of factors that can predispose an athlete to injury.

Age, previous injury and low fitness were usually found responsible for the increase of injury risk among sportsmen $[14,15]$. Correlated with higher 
injury risk were also found cigarette smoking [16], strength and flexibility imbalances [17] and stature [18].

According to the results of our study, the risk of injury among elite rugby players can be identified not only by using fitness tests, but also by using a simple and objective test of body composition.

It has already been shown in other studies that BMI and body fat may influence the risk of injury [19], but we are not aware of the existence of other studies that have identified a correlation between edema scores and risk of injury. Further studies are needed in order to verify and explain these results. Our results show how important it is to monitor the level of body fat, body water (including edema scores) and lean muscle mass in order to modify nutrition and food habits, individualize trainings and thus reduce the number of injuries.

In order to avoid injuries we need to make sure that the rugby players have a balanced, well-structured and tailored training. We also have to take in consideration the appropriate warm up and cool down period during training and competition games. The sportsman body needs also an appropriate training diet, resting time and recovery. Fluid and mineral needs should be covered but not exceeding in order to maintain the body composition balanced.

\section{References}

1. Gray J. (2009) Preventative rehabilitation for rugby injuries to the shoulder complex - evidence-based literature review. BokSmart.

2. Bathgate A, Best J.P, Craig G, Jamieson M.( 2002) A prospective study of injuries to elite Australian rugby union players. British Journal of Sports Medicine. 36: 265-269.

3. Best J.P, Mcintosh A.S., Savage T.N. (2005) Rugby World cup 2003 injury surveillance project. British Journal of Sports Medicine. 39: 812-812.

4. Bird Y.N., Waller S.W., Marshall S.W. (1998) The New Zealand rugby injury and surveillance project. Epidemiology of a season of rugby union. British Journal of Sports Medicine. 32: 319- 325.

5. Brooks J., Fuller C.W, Kemp S.P.T, Reddin D.B. (2005) $A$ prospective study of injuries and training amongst the England 2003 Rugby World Cup squad. British Journal of Sports Medicine. 39: 288-293.
6. Brooks J., Fuller C.W., Kemp S.P.T, Reddin D.B. (2005) Epidemiology of injuries in English professional rugby union: Part 1 match injuries. BrJ Sports Med ; 39: 757-766.

7. Brooks J., Fuller C.W., Kemp S.P.T., Reddin D.B. (2005). Epidemiology of injuries in English professional rugby union: Part 2 training injuries. Br J Sports Med ; 39: 767-775.

8. Junge A., Cheung K., Edwards T., Dvorak J.( 2004) Injuries in youth amateur soccer and rugby-comparison of incidence and characteristics. British Journal of Sports medicine. 38: 168-172.

9. Targett S.G.R. (1998) Injuries in professional rugby union. Clinical Journal of Sports Medicine. 8: 280-285.

10. Brooks J., Kemp S.P.T. (2008) Recent trends in rugby union injuries. Clinics in Sports Medicine. 27: 51-73.

11. Headey J., Brooks J.H.M., Kemp S.P.T. (2007) The epidemiology of shoulder injuries in English professional rugby union. The American Journal of Sports Medicine. 35 (9): 1537-1543.

12. Nicholas C.W. (1997) Anthropometric and physiological characteristics of rugby union football players. Sports Med. 23(6):375-96.

13. Bahr R., Holme I. (2003) Risk factors for sports injuries -a methodological approach. Br J Sports Med; 37:384- 392.

14. Arnason A. et al. (2004) Risk Factors for Injuries in Football. Am J Sports Med, 32 5S-16S.

15. Knapik J.J. et al. (2001) Discharges during U.S. Army basic training: injury rates and risk factors. Medicine and Science in Sports and Exercise, 33(6):946-954.

16. Knapik J.J. et al. (2001) Risk factors for training-related injuries among men and women in basic combat training. Medicine and Science in Sports and Exercise, 33(6):946954.

17. Knapik J.J. et al. (1991) Preseason strength and flexibility imbalances associated with athletic injuries in female collegiate athletes. Am J Sports Med, vol. 19 ;1 76-81.

18. Bruce H. Jones et al. (1993) Intrinsic risk factors for exercise-related injuries among male and female army trainees. Am J Sports Med, vol. 21, 5 :705-710.

19. Gómez J.E. et al. (1998) Body Fatness and Increased Injury Rates in High School Football Linemen. Clinical Journal of Sport Medicine:Volume 8 - Issue 2. 